\title{
Joining Galvanized Steel Sheets with Plastics by the RESISTANCE SOLDERING OF BIMETALLIC ELEMENTS
}

\author{
Branislav Vanko, Pavol Sejc \& Alexander Schrek
}
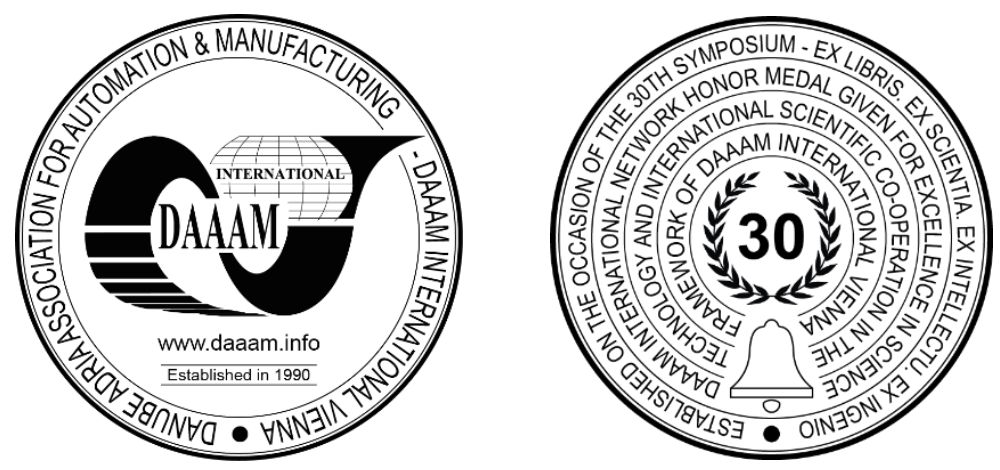

This Publication has to be referred as: Vanko, B[ranislav]; Sejc, P[avol] \& Schrek, A[lexander] (2021). Joining Galvanized Steel Sheets with Plastics by the Resistance Soldering of Bimetallic Elements, Proceedings of the 32nd DAAAM International Symposium, pp.0527-0535, B. Katalinic (Ed.), Published by DAAAM International, ISBN 9783-902734-33-4, ISSN 1726-9679, Vienna, Austria DOI: $10.2507 / 32$ nd.daaam.proceedings.076

\begin{abstract}
The proposed method of joining galvanized steel sheets with plastics by the resistance soldering of bimetallic elements provides a permanent joint of two dissimilar materials without breaking the zinc layer of the steel sheets and thermal degradation of the plastics. The method is based on the principle of the resistance element welding (REW) but uses innovative bimetallic joining elements with a hard case and low-melting core enabling joining at lower temperatures (up to $450{ }^{\circ} \mathrm{C}$ ). It is a suitable alternative for joining plastics to galvanized steel sheets by adhesive bonding or using rivets and screws. This article describes the method in detail and presents the first laboratory tests. The advantage of the method is an intact zinc layer of the steel sheets, non-degraded plastics, possibility to use almost all plastics and a smooth surface of reverse side of the steel sheets without visible joints. The disadvantage of the method is a lower strength of the joints and a more exacting production of joining elements. The use of the method requires solving the problems of creating stronger joints and reliable production of bimetallic elements.
\end{abstract}

Keywords: Metal-to-Plastic Joining; Resistance Element Welding; Soldering; Bimetallic Elements.

\section{Introduction}

In practice, it is often necessary to join dissimilar materials, for example metals with plastics, which can be problematic due to the requirements for the properties or the look of the joints. Plastics are light and cost-effective, but generally have relatively low mechanical properties and a low softening or degradation temperature [1], [2]. When joining plastics to galvanized steel sheets, which are widely used especially in the automotive industry, emphasis is placed not only on the final quality of the joint, but also the condition of plastics and the zinc layer of the steel sheets after joining. For joining such a combination of materials, it is possible to use, for example, riveting [3], [4], [5], [6], clinching [3], [4], [5], [6] or screwing [3], [4], [5], but these methods create undesirable protrusions on the joined materials and in many cases the zinc layer of the steel sheet is disrupted at the joint. This is the cause of later corrosion. Suitable alternatives are various welding methods [3], [4], [5], [6], [7], which also disrupt the protective zinc layer, or gluing [3], [4], [5], [ 6], [8], which may not be applicable to every plastic and a long curing time is usually required. 
As an alternative to all these methods, it was designed a new hybrid mechanical-metallurgical method of joining such a combination of materials using the principle of resistance element welding (REW) technology [3], [9], which is currently used mainly in the automotive industry for joining steel sheets with aluminum components. The purpose of the study is to validate this new hybrid method of joining galvanized steel sheets with plastics.

The principle of the REW technology (Fig. 1) comprises the use of a steel joining element (weld rivet) with a cylindrical shank and a head, by means of which an overlap joint of the upper pre-punched cover sheet with the lower base sheet is created by resistance heating. Resistance heating is used to create the weld nugget. For applying REW, a resistance welding gun primarily intended for resistance spot welding (RSW) is used. This involves the creation of a fusion joint between the base sheet and the joining element in combination with a formation of a mechanical joint between the joining element and the cover sheet.

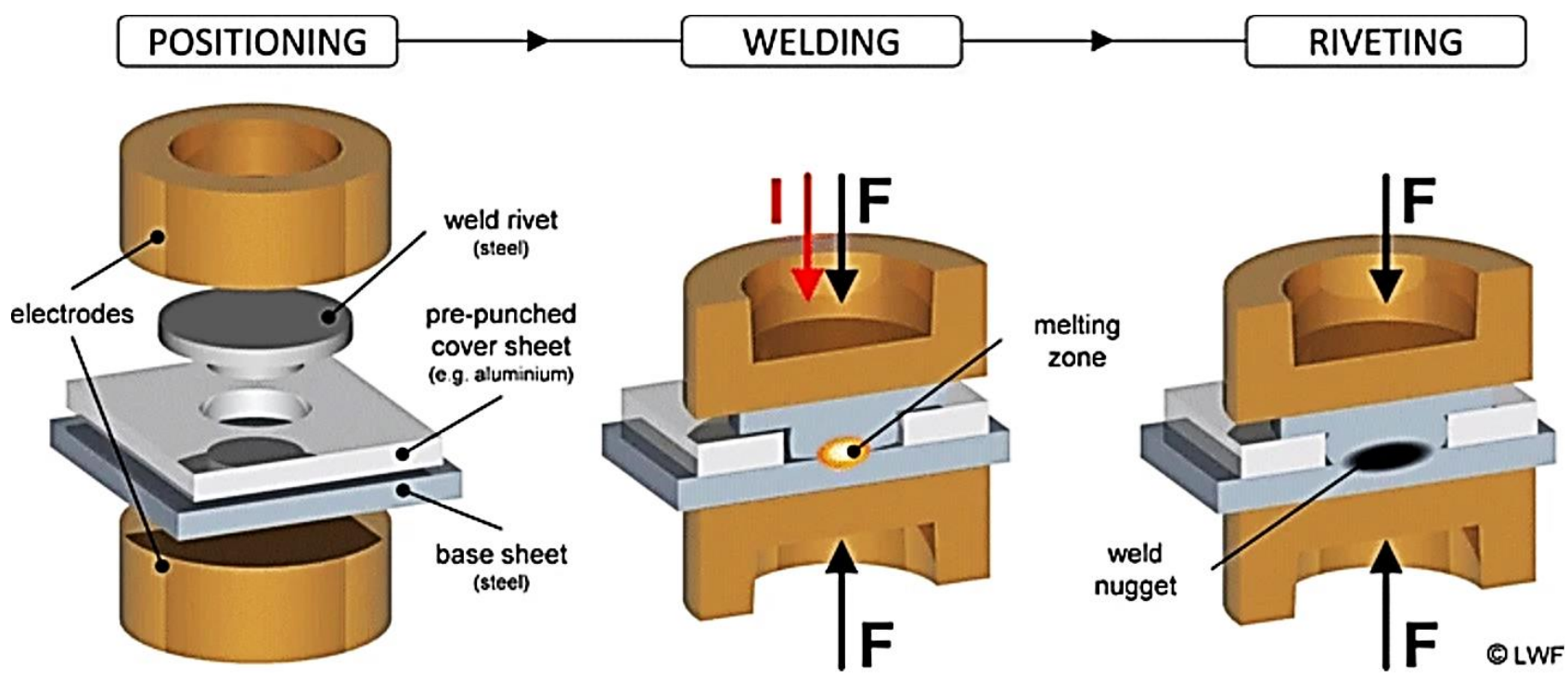

Fig. 1. The principle of welding by REW technology [9]

The main process parameters of the REW are welding time, welding current, and clamping force. Welding time is defined as the time during which the welding current flows through the welded materials. Welding time must be long enough to cause the joining element to melt, but, at the same time, as short as possible to avoid over-heating of the weld area. The clamping force influences the thermal phenomena during welding by affecting the transition resistance between the materials and ensuring that the welded materials are assembled and remain in contact. Unlike conventional RSW, the clamping force also ensures the deformation of the joining element. If the clamping force is sufficiently high, a tight force contact is formed between the joining element and the cover sheet due to deformation.

A solution for joining metal-to-plastic by REW technology can be the use of a joining element made of a material suitable for soldering the galvanized steel base sheet (e.g. tin-based solder). Thus, the joint between the joining element and the steel base sheet does not occur by fusion welding but by soldering. When joining, the steel sheet is only heated to a soldering temperature. Solders have a melting point of less than $450{ }^{\circ} \mathrm{C}$. This is much lower than a fusion welding temperature. Lower heat input reduces heat-induced stresses and deformations that occur during heating and cooling. Plastic cover sheet with a very low softening and degradation temperature can be joined to the steel base sheet without unwanted thermal degradation. Thermal degradation of the plastic sheet significantly affects the appearance, quality, and strength of the joint.

Unfortunately, solders have a significantly lower strength than the steel used for joining elements in REW. Thus, the use of solder materials to produce a joining element for REW technology does not fulfill the condition to produce the desired tight force contact with the plastic cover sheet. Therefore, it was designed a unique bimetallic joining element consisting of a hard case and a soft core. The case was made of a $\mathrm{Cu}$ tube and the core was made of a Sn60Pb40 solder. The hard case can create sufficient force contact between the plastic cover sheet and the steel base sheet. The soft core is suitable for soldering of galvanized steel sheets. The melting point of the Sn60Pb40 solder is lower than the thermal degradation temperature of most thermoplastics. The mechanical properties of the $\mathrm{Cu}$ tube and the $\mathrm{Sn} 60 \mathrm{~Pb} 40$ solder are given in Table 1. The shape and dimensions of the bimetallic elements are shown in Fig. 2.

\begin{tabular}{|l|l|l|l|l|}
\hline Material & $\begin{array}{l}\text { Yield Strength } \\
\text { YS [MPa] }\end{array}$ & $\begin{array}{l}\text { Tensile Strength } \\
\text { UTS }[\mathbf{M P a}]\end{array}$ & $\begin{array}{l}\text { Elongation to Fracture } \\
\mathbf{A}[\%]\end{array}$ & $\begin{array}{l}\text { Melting Point } \\
\mathbf{T}_{\mathbf{M}}\left[{ }^{\circ} \mathbf{C}\right]\end{array}$ \\
\hline $\mathrm{Cu}$ & $60 \div 220(290)$ & $200 \div 300(345)$ & $4 \div 30(4)$ & 1083 \\
\hline $\mathrm{Sn} 60 \mathrm{~Pb} 40$ & $-(40)$ & $40 \div 80(60)$ & $40(11)$ & $183 \div 190$ \\
\hline
\end{tabular}

Table 1. Basic properties of $\mathrm{Cu}$ and $\mathrm{Sn} 60 \mathrm{~Pb} 40$ from the literature $[10,11]$ and measured given in brackets 


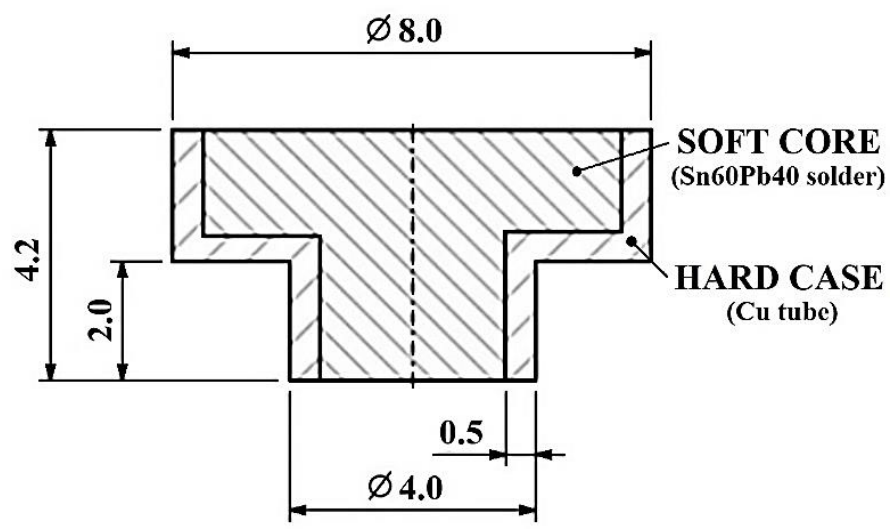

Fig. 2. Shape and dimensions of bimetallic element

\section{Experiment}

Bimetallic elements were made by casting molten solder into a hot $\mathrm{Cu}$ tube $(\mathrm{D}=4 \mathrm{~mm})$ housed in a graphite case against an unheated graphite plate as shown in Fig. 3. The casting temperature and the preheating temperature of the $\mathrm{Cu}$ tube in the graphite case were $210^{\circ} \mathrm{C}$. Prior to casting, a flux was applied to the $\mathrm{Cu}$ tube to remove surface oxides and improve the wettability. The semi-finished products were cut into short pieces of the required length, which were cold formed by the upsetting process (Fig. 4) in the shape of joining elements (Fig. 5).

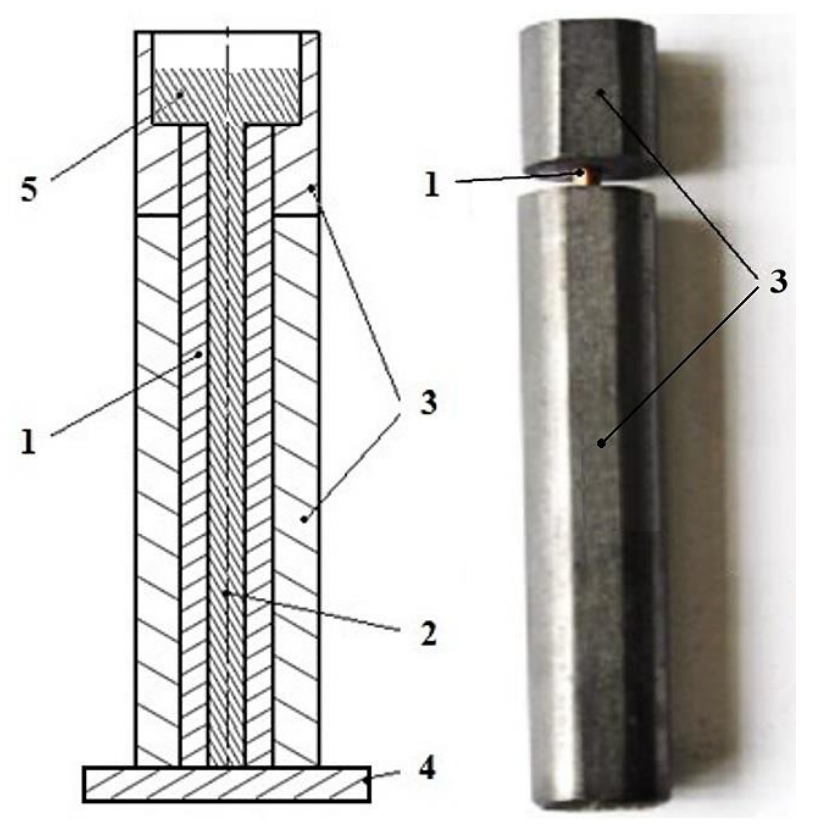

Fig. 3. Casting of semi-finished product for the forming of bimetallic elements (1 - Cu tube, 2 - Sn60Pb40 solder, 3 - graphite case, 4 - graphite plate, 5 - pouring cup)

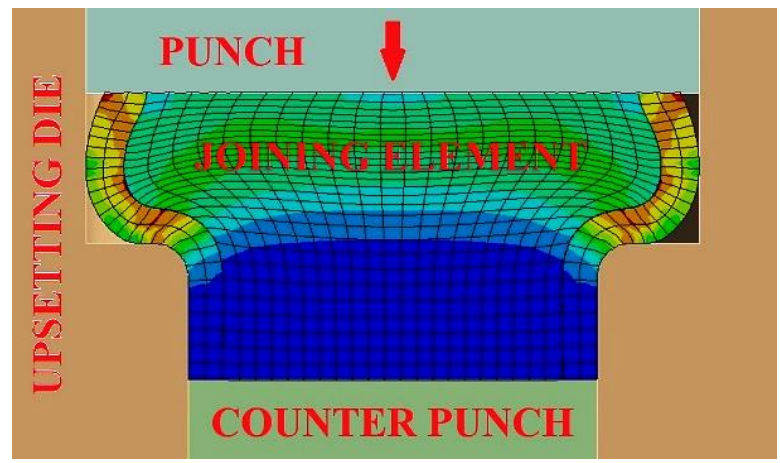

Fig. 4. Cold forming of the bimetallic element by the upsetting process 


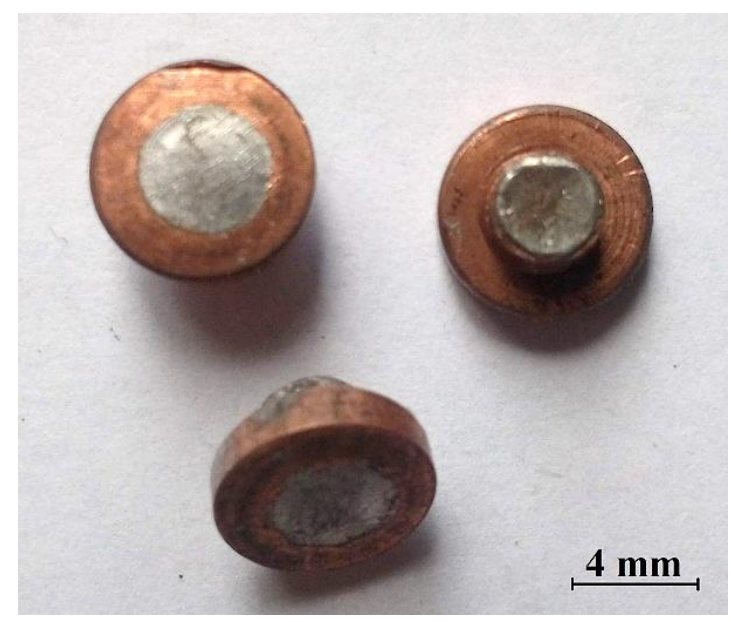

Fig. 5. Finished bimetallic elements

In these first experiments, there was a problem in achieving a good quality of the bimetallic elements. During casting, defects occurred in the form of the porosity of the solder, and during forming, wrinkles and eccentricity were formed (Fig. 6). Defects that were not evident after the production of bimetallic elements during joining caused problems and did not create quality joints (Fig. 7). These defects could also affect the resulting mechanical properties of the joints, which at first look appeared to be of good quality.

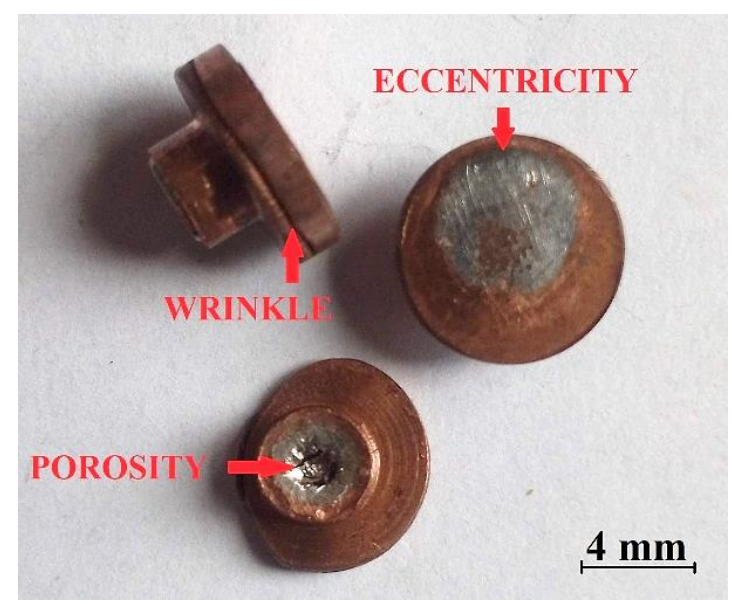

Fig. 6. Defects detected on the bimetallic elements (porosity, wrinkle, eccentricity)
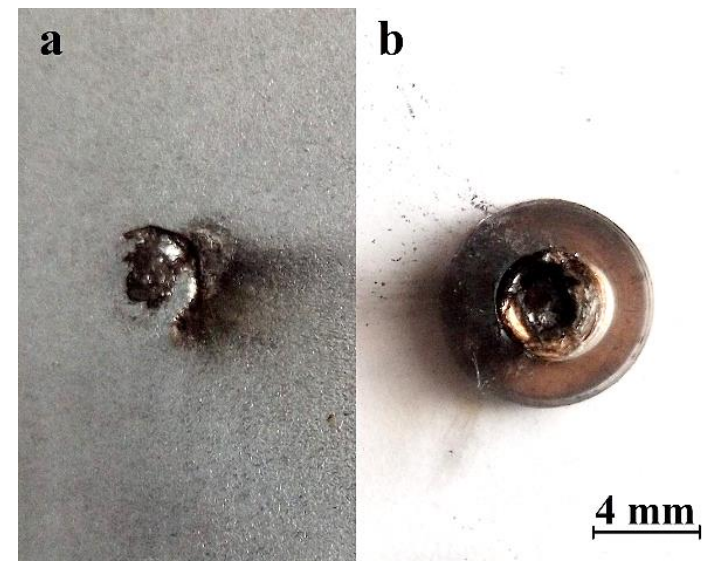

Fig. 7. Joint defect due to hidden porosity in the joining element: a) steel sheet; b) bimetallic element

To verify the proposed hybrid metal-to-plastic joining method the both side galvanized bake-hardening steel sheet HX220BD with a thickness of $0.8 \mathrm{~mm}$ and a 100MBO type zinc coating (approx. $15 \mu \mathrm{m}$ of $\mathrm{Zn}$ ) was used. Chemical composition and mechanical properties of the steel are given in Table 2 and Table 3. 


\begin{tabular}{|l|l|l|l|l|l|l|}
\hline $\mathbf{C}$ & $\mathbf{T i}$ & $\mathbf{S i}$ & $\mathbf{M n}$ & $\mathbf{P}$ & $\mathbf{S}$ & $\mathbf{N b}$ \\
{$[\%]$} & {$[\%]$} & {$[\%]$} & {$[\%]$} & {$[\%]$} & {$[\%]$} & {$[\%]$} \\
\hline 0.1 & 0.12 & 0.5 & 0.7 & 0.01 & 0.03 & 0.09 \\
\hline
\end{tabular}

Table 2. Chemical composition of HX220BD bake-hardening steel [12]

\begin{tabular}{|l|l|l|}
\hline $\begin{array}{l}\text { Yield Strength } \\
\text { YS [MPa] }\end{array}$ & $\begin{array}{l}\text { Tensile Strength } \\
\text { UTS [MPa] }\end{array}$ & $\begin{array}{l}\text { Elongation to Fracture } \\
\text { A [\%] }\end{array}$ \\
\hline $220 \div 280$ & $320 \div 400$ & 32 \\
\hline
\end{tabular}

Table 3. Basic mechanical properties of HX220BD bake-hardening steel [12]

The steel sheet was joined to the QUINN XT PMMA (Polymethyl Methacrylate) thermoplastic, which was colorless and $2 \mathrm{~mm}$ thick. PMMA is primarily intended for deep hot drawing, polishing, gluing, as well as a construction element used for manufacturing safety covers and parts for the instruments. The basic properties of this thermoplastic material are shown in Table 4. The PMMA degradation temperature is $90{ }^{\circ} \mathrm{C}$ higher than the melting point of the $\mathrm{Sn} 60 \mathrm{~Pb} 40$ solder (see Table 1).

\begin{tabular}{|l|l|l|l|l|}
\hline $\begin{array}{l}\text { Tensile } \\
\text { Strength } \\
\text { UTS }[\mathrm{MPa}]\end{array}$ & $\begin{array}{l}\text { Elongation } \\
\text { to Fracture } \\
\mathrm{A}[\%]\end{array}$ & $\begin{array}{l}\text { Vicat Softening } \\
\text { Temperature } \\
\mathbf{T}_{\mathbf{S}}\left[{ }^{\circ} \mathbf{C}\right]\end{array}$ & $\begin{array}{l}\text { Degradation } \\
\text { Temperature } \\
\mathbf{T}_{\mathbf{D}}\left[{ }^{\circ} \mathbf{C}\right]\end{array}$ & $\begin{array}{l}\text { Max. Temperature } \\
\text { Short Term Use } \\
\mathbf{T}_{\mathbf{X}}\left[{ }^{\circ} \mathbf{C}\right]\end{array}$ \\
\hline 70 & 4 & 110 & 280 & 90 \\
\hline
\end{tabular}

Table 4. Basic properties of QUINN XT PMMA plastic [13]

The position of the materials before joining is shown in Fig. 8. After cutting the material to a required size, a hole (d $=4.1 \mathrm{~mm})$ with a recess $(\mathrm{D}=8.1 \mathrm{~mm}, \mathrm{~h}=1 \mathrm{~mm})$ was drilled into the thermoplastic to insert the joining element. Before joining, galvanized steel sheets were cleaned of grease and dirt with acetone. Subsequently, SF-601 liquid flux was applied to the surface of the steel sheet at the connection point area.
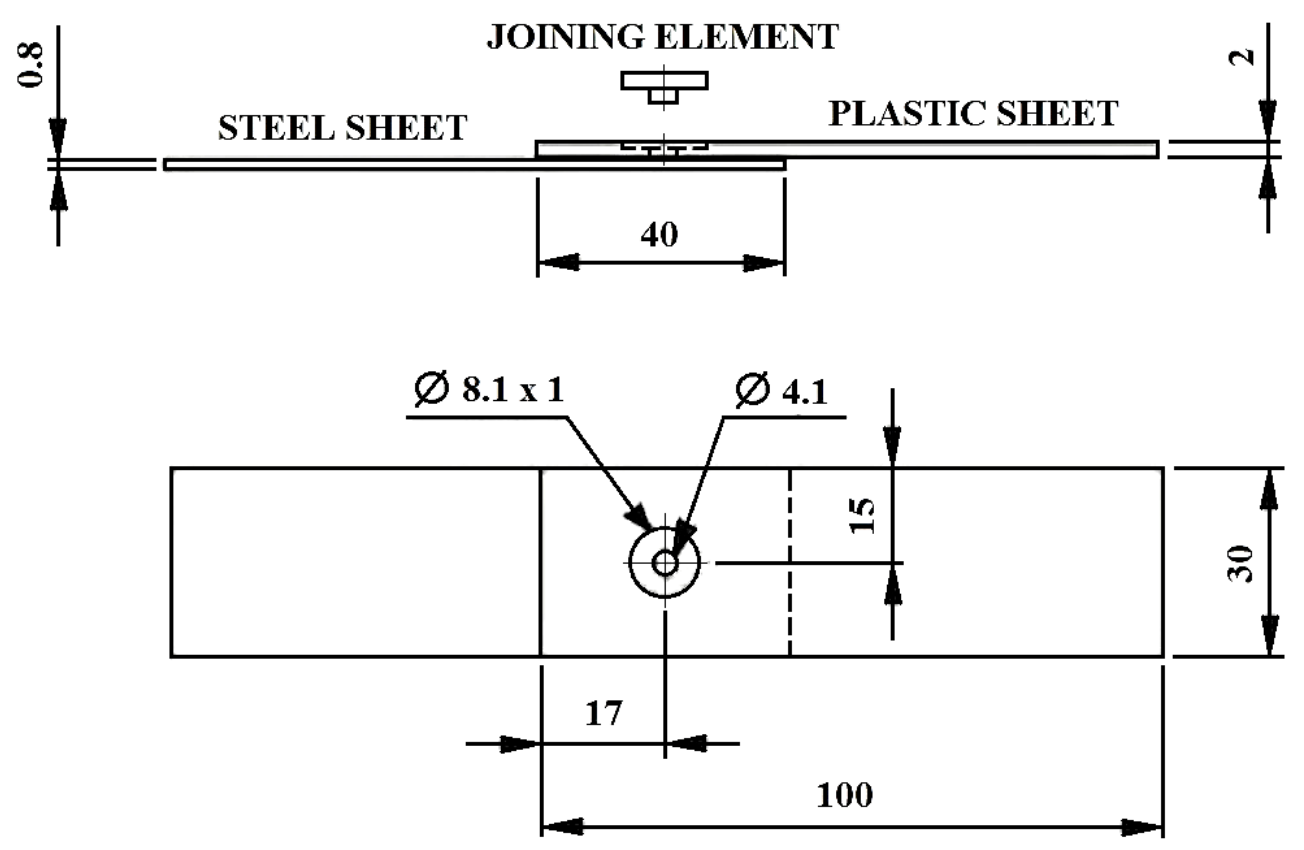

Fig. 8. Dimensions and position of joined materials

The ARO type XMA $26 \mathrm{kVA}$ resistance welding gun with ULB 1.4 universal VTS control system was used for heating of materials at the joint. The parameters were set as follows: welding (soldering) current $\mathrm{I}=3.5 \mathrm{kA}$, clamping force $\mathrm{F}=1610 \mathrm{~N}$, and heating (soldering) time $\mathrm{t}=10,15$ and 20 cycles. For a $50 \mathrm{~Hz}$ power supply, one cycle last 20 milliseconds. By changing the time, the heat input $(\mathrm{Q})$ to the joint was regulated. The real values of the selected process parameters were measured by using the Miyachi measuring device of the Weld Checker MM-356 B type. The set and measured process variables of current, voltage, heating time and heat input are given in Table 5. 
The type II (CuCrZr) electrodes designed for RSW of galvanized steel sheets were used. On the side of the joining element, an electrode with a planar contact surface (FC geometry type) was used. On the side of the galvanized steel sheet, an electrode with a rounded surface (FB geometry type) was used. In addition to the electrical current supply, the planar surface of the electrode had the task of positioning the joining element in such a way that its axis was perpendicular to the surface of the steel sheet.

\begin{tabular}{|l|l|l|l|l|l|l|}
\hline \multirow{2}{*}{$\begin{array}{l}\text { Sample } \\
\text { No. }\end{array}$} & $\begin{array}{l}\text { Set Parameters } \\
\text { Current } \\
\mathbf{I}[\mathbf{k A}]\end{array}$ & $\begin{array}{l}\text { Clamping Force } \\
\mathbf{F}[\mathbf{N}]\end{array}$ & $\begin{array}{l}\text { Heating Time } \\
\mathbf{t}[\mathbf{c y c l e s}(\mathbf{m s})]\end{array}$ & $\begin{array}{l}\text { Measured Parameters } \\
\mathbf{I}[\mathbf{k A}]\end{array}$ & $\begin{array}{l}\text { Voltage } \\
\mathbf{U}[\mathbf{V}]\end{array}$ & $\begin{array}{l}\text { Heat Input } \\
\mathbf{Q}[\mathbf{J}]\end{array}$ \\
\hline 1. & 3.5 & 1610 & $10(200)$ & 3.50 & 0.42 & 294 \\
\hline 2. & 3.5 & 1610 & $10(200)$ & 3.52 & 0.42 & 296 \\
\hline 3. & 3.5 & 1610 & $10(200)$ & 3.51 & 0.42 & 295 \\
\hline 4. & 3.5 & 1610 & $10(200)$ & 3.50 & 0.41 & 287 \\
\hline 5. & 3.5 & 1610 & $15(300)$ & 3.62 & 0.36 & 391 \\
\hline 6. & 3.5 & 1610 & $15(300)$ & 3.61 & 0.37 & 401 \\
\hline 7. & 3.5 & 1610 & $15(300)$ & 3.60 & 0.38 & 410 \\
\hline 8. & 3.5 & 1610 & $15(300)$ & 3.67 & 0.35 & 385 \\
\hline 9. & 3.5 & 1610 & $20(400)$ & 3.62 & 0.37 & 536 \\
\hline 10. & 3.5 & 1610 & $20(400)$ & 3.60 & 0.38 & 547 \\
\hline 11. & 3.5 & 1610 & $20(400)$ & 3.61 & 0.37 & 534 \\
\hline 12. & 3.5 & 1610 & $20(400)$ & 3.63 & 0.37 & 537 \\
\hline
\end{tabular}

Table 5. Set and measured parameters of joining process

\section{Results and discussion}

After overcoming the initial complications of setting the correct welding position with a welding jig, a series of joints was created according to the parameters listed in Table 5. The variable parameter was the heating time by which the heat introduced into the joint (heat input) was regulated. The joints could be reliably made with a heating time in the range of 10 to 20 cycles. In an attempt to use heating times longer than $t \geq 25$ cycles, there were persistent manufacturing problems, so these joints were included in this study only marginally, when examining the crosssectional appearance of the joints. A typical appearance of the joints is presented in Fig. 9 and Fig. 10.
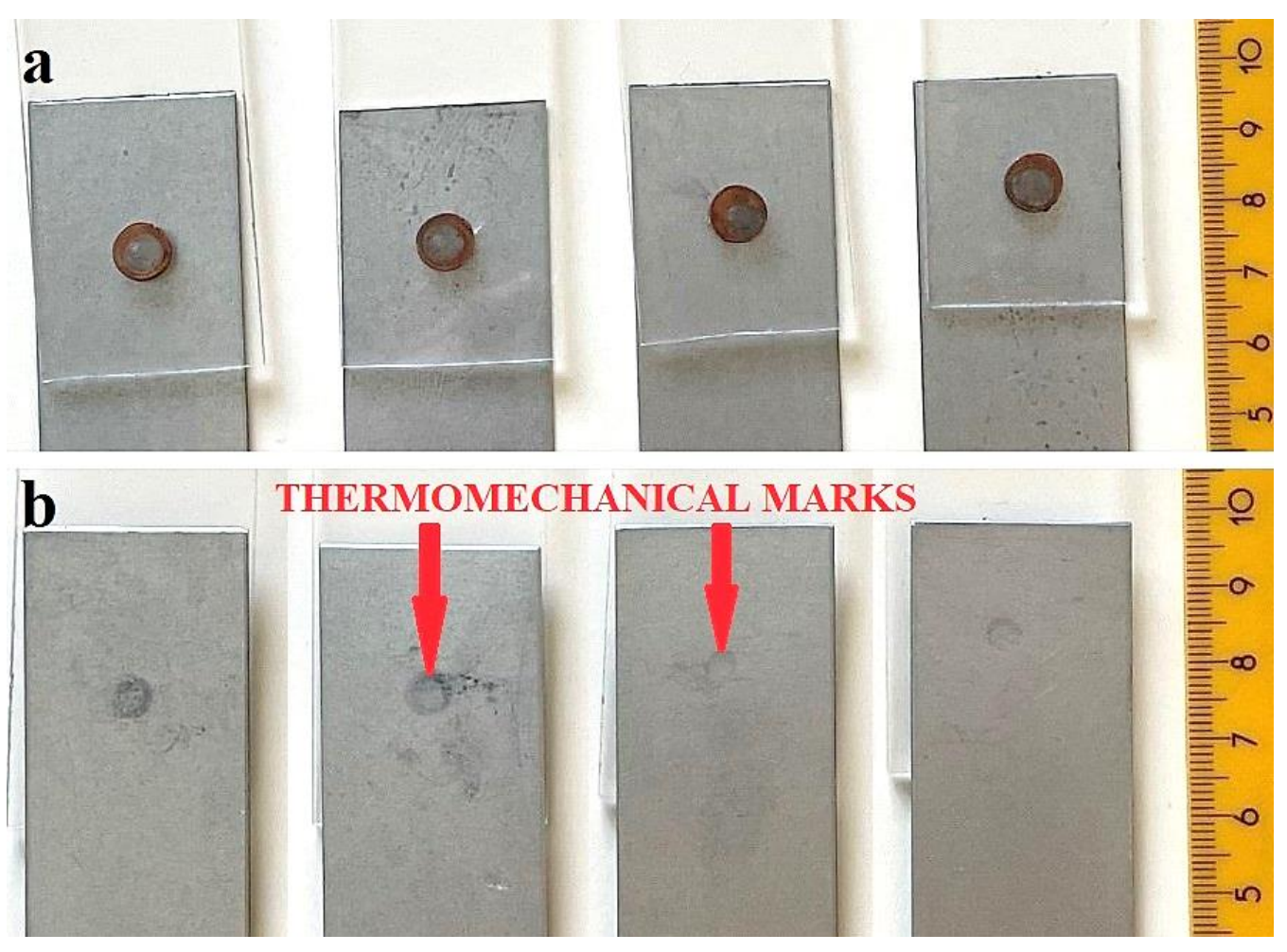

Fig. 9. Samples no. 5, 6, 7 and $8(\mathrm{t}=15$ cycles $)$ : a) viewed from the side of joining elements and plastic sheets; b) viewed from the side of galvanized steel sheets 

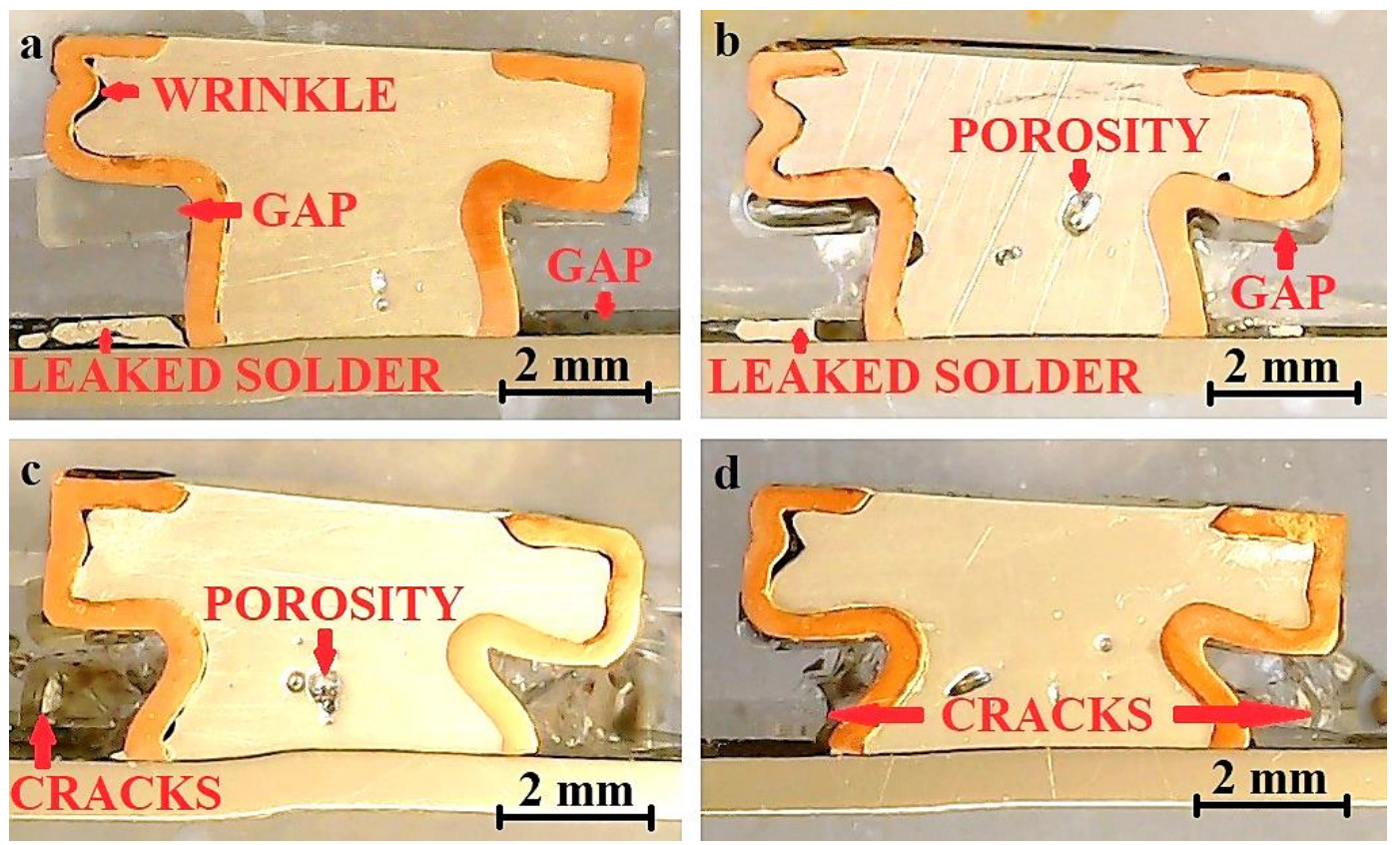

Fig. 10. Samples made with different heating times in cross section view: a) $t=10$ cycles; $b) t=15$ cycles; c) $t=20$ cycles; $d) t=25$ cycles

In Fig. 9, it can be seen that the undersides of the steel sheets have imprints from the welding electrode (thermomechanical marks), but the zinc layer has not been broken. This protective anti-corrosion layer was not broken in any joining mode. Also, the plastic did not degrade in any joining mode, but at longer heating times ( $\mathrm{t} \geq 20$ cycles) micro-cracks formed in the plastic during joining, due to excessive deformation of the shank of the joining element (Fig. $10 \mathrm{c}$ and Fig. $10 \mathrm{~d}$ ). This deformation was caused by excessive heating and softening of the joining element due to the large amount of heat introduced into the joints (heat input). Micro-cracks in the joint area occasionally caused the plastic and not the solder joint to break during the tensile test. In contrast, the small amount of heat introduced at shorter heating times ( $t \leq 15$ cycles) did not cause sufficient deformation of the shank of the joining element to form a tight force connection between the plastic and the joining element (Fig. $10 \mathrm{a}$ and Fig. $10 \mathrm{~b}$ ). From this point of view, between 15 and 20 cycles seems to be the most suitable heating time. For future experiments, it is worth considering a small increase in the diameter of the pre-drilled hole in the plastic sheet or a shortening of the shank of the joining element, which should ensure less cracking in the plastic during joining.

In Fig. 10 it can be seen that the right sides of the joining elements are more compressed than the left side, i.e. the absolute perpendicularity of the joined sheets to the welding electrodes was not observed during the joining. This deviation from the perpendicularity did not have a significant effect on the quality of the joints.

The tensile test was performed using the Instron 1195 universal testing machine. A typical fracture surface after the tensile test is shown in Fig. 11 on which it can be seen that the solder wets the surface of the galvanized steel sheet very well and forms a high-quality soldered joint. It can be seen in the Fig. 10 and Fig. 11 that a small amount of solder can leak or spurt out between the plastic and the steel sheet during the process of joining. The results of tensile test of overlap joints are shown in Table 6.

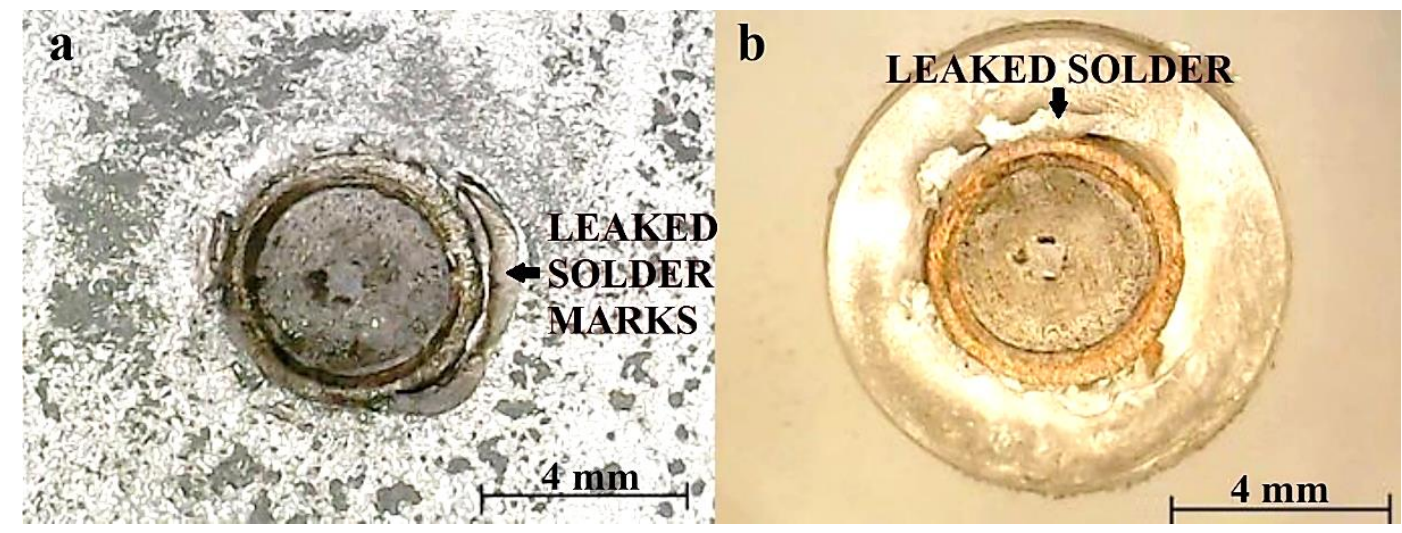

Fig. 11. Detail of the fracture surface of sample no. $6(t=15$ cycles $)$ after the tensile test: a) galvanized steel sheet; b) bimetallic element in the plastic sheet 


\begin{tabular}{|l|l|l|l|l|l|}
\hline $\begin{array}{l}\text { Sample } \\
\text { No. }\end{array}$ & $\begin{array}{l}\text { Clamping Force } \\
\text { F }[\mathbf{N}]\end{array}$ & $\begin{array}{l}\text { Heating Time } \\
\mathbf{t}[\text { cycles }(\mathbf{m s})]\end{array}$ & $\begin{array}{l}\text { Heat Input } \\
\mathbf{Q}[\mathbf{J}]\end{array}$ & $\begin{array}{l}\text { Max. Tensile Force } \\
\mathbf{F}_{\text {Tmax }}[\mathbf{N}]\end{array}$ & $\begin{array}{l}\text { Standard } \\
\text { Deviation }\end{array}$ \\
\hline 1. & 1610 & $10(200)$ & 294 & 416 & \\
\hline 2. & 1610 & $10(200)$ & 296 & 308 & \\
\hline 3. & 1610 & $10(200)$ & 295 & 241 & \\
\hline 4. & 1610 & $10(200)$ & 287 & Lost Sample & \\
\hline Average value & 1610 & $10(200)$ & 293 & 322 & 88 \\
\hline 5. & 1610 & $15(300)$ & 391 & 186 & \\
\hline 6. & 1610 & $15(300)$ & 401 & 425 & \\
\hline 7. & 1610 & $15(300)$ & 410 & 493 & \\
\hline 8. & 1610 & $15(300)$ & 385 & 291 & 137 \\
\hline Average value & 1610 & $15(300)$ & 397 & 349 & \\
\hline 9. & 1610 & $20(400)$ & 536 & 515 & \\
\hline 10. & 1610 & $20(400)$ & 547 & 632 & \\
\hline 11. & 1610 & $20(400)$ & 534 & 472 & 124 \\
\hline 12. & 1610 & $20(400)$ & 537 & 331 & \\
\hline Average value & 1610 & $20(400)$ & 539 & 488 & \\
\hline
\end{tabular}

Table 6. Tensile test results

The average values of the joint strength (evaluated by the average values of the maximum tensile force) ranged from $322 \mathrm{~N}(\mathrm{t}=10$ cycles) to $488 \mathrm{~N}(\mathrm{t}=20$ cycles), but the variance of the measurements was quite large (see standard deviations in the Table 6). The results showed that the heating time (heat input) influence the mechanical properties of the joints made by a bimetallic element. As the heat input increased, the deformation of the joining element shank increased (see Fig. 10), which caused a larger contact area between the joining element and the steel sheet, therefore the strength of the joint increased.

Samples with a preheating time $t \geq 25$ cycles were not tested because there were not enough of them. During production, solder escaped from the top of the joining element (contact area between the welding electrode and the joining element), which caused the higher deformation of the joining element and more extensive cracking of the plastic sheet. This phenomenon occurred because there was too much molten solder (about $90 \%$ ) in the bimetallic element due to the large amount of heat input. To create a quality joint the ideal amount of remelted solder is about 70 to $80 \%$, which occurred at a heating time of 15 and 20 cycles (Fig. 12).

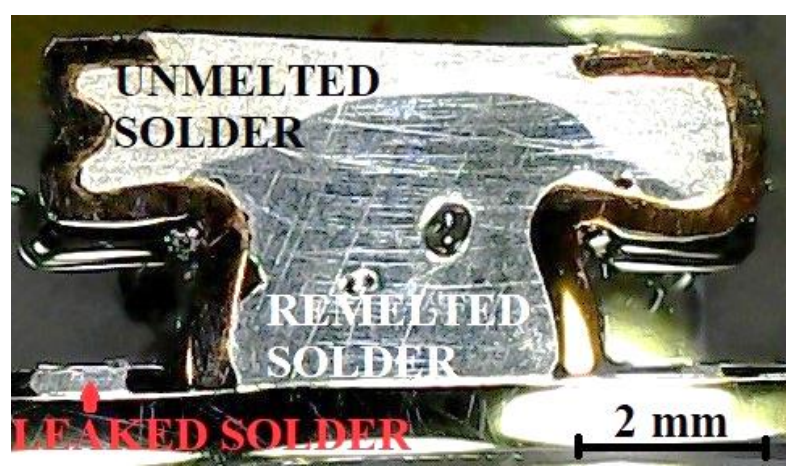

Fig. 12. Sample no. $8(\mathrm{t}=15$ cycles $)$ with approximately $70 \%$ of remelted solder in the joint

\section{Conclusion}

The proposed hybrid mechanical-metallurgical method of joining galvanized steel sheets with plastics using bimetallic elements without thermal degradation of plastics and breaking of the galvanized layer has been successfully verified. After the production of the first bimetallic elements of acceptable quality, reliable joints were successfully created which could be mechanically loaded. The tensile load for breaking the joint was relatively low, the average value of the tensile force ranged from 322 to $488 \mathrm{~N}$, in addition with a large variance of the values (deviation from the average value), so it is necessary to optimize this method of joining dissimilar materials.

Based on the achieved results, it was concluded that the strength of joints cannot be increased by changing process parameters such as heating time, because there is only one optimal setting of the joining process, which will bring quality and strong joints. For a given current of $3.5 \mathrm{kA}$ and a clamping force of $1610 \mathrm{~N}$, the optimal heating time would be somewhere between 15 and 20 cycles, which will provide the required amount of molten solder in the joining element (about 70 to $80 \%$ ), and this will allow the required deformation of the element shank. 
The strength of the joints was affected by the size of the contact area between the joining element and the steel sheet and the quality of the bimetallic elements. For this reason, a larger diameter of the $\mathrm{Cu}$ tube $(\mathrm{D}=6 \mathrm{~mm})$, a modified technology of filling the $\mathrm{Cu}$ tube with solder and a new tool for forming the joining elements were chosen for further experiments.

In further experiments, we would like to verify the quality and reliability of bimetallic elements produced by a new technological process, evaluate the impact of a larger contact area between the joining element and the steel sheet on the mechanical properties, and optimize the size of the hole for the joining element. Furthermore, we would like to replace the $\mathrm{Sn60Pb} 40$ solder, which due to its lead content is not in accordance with the EU Directive 2002/96/EC on Waste Electrical and Electronic Equipment (WEEE Directive) of 2003, a lead-free solder (e.g. Sn91Zn9) or a solder suitable for soldering other metallic materials, e.g. aluminum alloys.

\section{Acknowledgments}

We thank the Slovak grant agency VEGA for financial support of the VEGA 1/0405/19 project and the University Science Park STU Bratislava for the support of the ITMS 26240220084 project.

\section{References}

[1] Pandzic, A[di]; Hodzic, D[amir] \& Milovanovic, A[leksa] (2019). Effect of Infill Type and Density on Tensile Properties of PLA Material for FDM Process, Proceedings of the 30th DAAAM International Symposium, pp.0545-0554, B. Katalinic (Ed.), Published by DAAAM International, ISBN 978-3-902734-22-8, ISSN 17269679, Vienna, Austria. DOI: 10.2507/30th.daaam.proceedings.074

[2] Pandzic, A[di]; Hodzic, D[amir] \& Milovanovic, A[leksa] (2019). Influence of Material Colour on Mechanical Properties of PLA Material in FDM Technology, Proceedings of the 30th DAAAM International Symposium, pp.0555-0561, B. Katalinic (Ed.), Published by DAAAM International, ISBN 978-3-902734-22-8, ISSN 17269679, Vienna, Austria. DOI: 10.2507/30th.daaam.proceedings.075

[3] Meschut, G.; Janzen, V. \& Olfermann, T. (2014). Innovative and Highly Productive Joining Technologies for Multi-Material Lightweight Car Body Structures. Journal of Materials Engineering and Performance, Vol. 23, May 2014, pp. 1515-1523. ISSN 1059-9495. DOI: 10.1007/s11665-014-0962-3

[4] Martinsen, K.; Hu, S. J. \& Carlson, B. E. (2015). Joining of Dissimilar Materials, In: CIRP Annals Manufacturing Technology, Vol. 64, Iss. 2, pp. 679-699, Elsevier, ISSN 0007-8506. DOI: 10.1016/j.cirp.2015.05.006

[5] Kah, P.; Suoranta, R.; Martikainen, J. \& Magnus, C. (2014). Techniques for Joining Dissimilar Materials: Metals and Polymers. Reviews on Advanced Materials Science, Vol. 36, No. 2, 2014, pp. 152-164, ISSN 1605-8127.

[6] Chastel, Y. \& Passemard, L. (2014). Joining Technologies for Future Automobile Multi-material Modules. Proceedings of Procedia Engineering 81, 11 th International Conference on Technology of Plasticity, ICTP 2014, 19-24 October 2014, Nagoya, Japan, ISSN 1877-7058, Ishikawa, T. \& Mori, K. (Ed.), pp. 2104 - 2110, Elsevier. DOI: $10.1016 /$ j.proeng.2014.10.293

[7] Katayama, S. \& Kawahito, Y. (2008). Laser Direct Joining of Metal and Plastic. Scripta Materialia. Vol. 59, Iss. 12, December 2008, pp. 1247-1250, ISSN 1359-6462. DOI: 10.1016/j.scriptamat.2008.08.026

[8] Banea, M. D. (2021). Dissimilar Joining of PMCs to Metals - Adhesive Bonding, In: Reference Module in Materials Science and Materials Engineering, Elsevier, ISBN 9780128035818. DOI: 10.1016/B978-0-12-8197240.00061-6

[9] Meschut, G.; Hahn, O., Janzen, V. \& Olfermann, T. (2014). Innovative Joining Technologies for Multi-Material Structures. Welding in the World, Vol. 58, January 2014, pp. 65-75, ISSN 1878-6669. DOI: 10.1007/s40194-0130098-3

[10] Vianco, P. T. (1999). Soldering Handbook, 3rd edition, American Welding Society, ISBN 978-0-87171-618-7.

[11] ASM Specialty Handbook: Copper and Copper Alloys (2001). Edited by J. R. Davis, Davis \& Associates, ASM International, ISBN 978-0-87170-726-8.

[12] https://www.usske.sk/en/products/hot-dip-galvanized/bake-hardening-steels, (2019). U. S. Steel Košice, BakeHardening Steels, Accessed on: 2021-07-07.

[13] http://vascony.com/wp-content/uploads/2014/01/en-quinn-xt-10-07.pdf, (2019). Quinn Plastics, Product Information: QUINN XT, Accessed on: 2021-07-07. 